\title{
ACUTE OTITIS MEDIA BACTERIOLOGICAL STUDY AND DRUG SENSITIVITY PATTERN
}

Rakesh Kumar ${ }^{1}$

HOW TO CITE THIS ARTICLE:

Rakesh Kumar. "Acute otitis media bacteriological study and drug sensitivity pattern". Journal of Evolution of Medical and Dental Sciences 2013; Vol2, Issue 38, September 23; Page: 7297-7301.

ABSTRACT: To study the clinical \& bacteriological pattern of acute otitis media (AOM) in pediatric age group along with the antibiotic sensitivity pattern. This is to strengthen the choice of antimicrobial agent in treatment of AOM. The present study was carried out at ENT Dept. Netaji Subhash Chandra Bose Medical College \& Hospital, Jabalpur from July 2004 to June 2005 and involved 100 outdoor patient of OM of which 46 pt were suffering from AOM. Aural swab was taken taking all aseptic precautions (like hand wash, sterile gloves, sterile aural swab stick) \& prior cleaning of External Auditory canal (EAC) with saline \& sprite. In the present study we have found streptococcus pneumonia \& staph aureus as most common causative organism. Antibiotic sensitivity pattern of the isolated organism showed cephalosporin \& Amikacin to be most effective. In conclusion, strepto pneumonia \& strepto aureus are the most common causative pathogen. Most of pathogens have developed multidrug resistance cephalosporin's are found most effective.

KEY WORDS: Acute otitis media streptococcus pneumonias, cephalosporin.

INTRODUCTION: Otitis media is defined as an inflammation of the middle ear cleft without reference etiology \& pathogenesis [6]. The middle ear cleft consist of the tympanic cavity (tympanum) the Eustachian tube and the mastoid air cell system. Otitis media is one of the common illness in pediatric age group fiellau Nikolajsen $(1979,83)$. Zielhuis \& van den Brock (1986). Though present in all age group on both sex it is more common in child hood (Ref 8, 12, 24).

Santeria 1980 classified OM on the basis of duration as. Acute $\leq 3$ week duration, sub acute 3 week -3 month \& chronic $>3$ month. Third and fourth international symposia on OM define ear infection on clinical ground dividing them into four groups:

- Myringitis,

- SOM ć effusion,

- Acute Suppurative otitis media (ASOM)

- Chronic Suppurative otitis media (CSOM)

Otitis media most commonly present with ear discharge hearing loss \& cough -cold which is followed by earache, tinnitus and fullness of ear (Ref 10,16, 21, 24).. The term supportive OM means a purulent inflammation of the middle ear cleft. The cause is often purely infective Jordal 1949, Jannefer M et al, Rosenfeld RM, Post JC 1992 but other such as allergy (Kroemer MJ, Richardson MA, weiss NS, et al 1983, Blakely BW, Blakely JE 1995), Chemical irritants, Auto immune disease (Ammann A3, Shannon K 1985 peltton et al, Suzuki et al 1988) and other may underlie the discharge (Ref 10,12,15). It is necessary to establish as to whether it is viral or bacterial in nolure. Viral OM is usually a consequence of upper respiratory virus ie Rhino virus, Respiratory syncitial virus which present as congestion and middle ear fluid accumulation (Singleton 1956, freeman 1960, Bylander 1982 \& fowler 1947). 


\section{ORIGINAL ARTICLE}

Bacterial infection present with sigh and symptoms of acute inflammation, pain in ear, congestion and bulging of tympanic membrane, white, yellow or turbid fluid it may be associated with malaise and mild pyrexia (Fiellau Nikolajsen 1979, 83 Zielhuis and vanden brook (1986) Gehenna et al 1992 Bluestone Stephenson \& martin 1992 Kenna MA 1993.)

Bacteriologically as well as etiologically both types are different. Due to prevalence of multiple pathogens and indiscriminate use of antibiotics the bacteriological scenario has changed. Vijaya D(2000), Parveen naheed (2000), Rao \& Reddy (1991.)

MATERIAL \& METHOD: The present study was carried out in a multi specialty Medical college \& Hospital dept. of ENT Jabalpur from July 2004 to June 2005.

46 patient of Acute OM which were grouped often screening 100 pt's of OM diagnosed on the basis of clinical examination.

External auditory canal of patient was cleaned with saline first followed by spirit to avoid contamination of culture material.

Taking all aseptic precautions like proper hand wash with aseptic solution wearing sterile gloves pus is taken from middle ear \& sent for culture and sensitivity following all standard protocols throat swab blood test \& urine test were all taken.

RESULT \& DISCUSSION: Out of 46 pt's of Acute OM, 8 patients were diagnosed as acute nonsuppurative OM (80\% Rt, 20\% Lt) (Lalwani \& Scoy 1992, Robbins Schneerson \& Szu 1988, De Moria et all 1984) and rest 38 belonged to ASOM category (53\% Rt, 21\% Lt \& 26\% both) the $9-12$ year age group was the more affection with more male patients than female. Vijaya $\mathrm{D}(62.77 \% \mathrm{~m})$ 1998, Parveen Nahud (62.03\%) 2002, Galati et all 1997 (61\%m).

Ear discharge 95\% Reduced hearing (50\%) BN Reddy MS 1991 (100\%) Gulati, Sudesh Kumar 1997 (65\%). \& cold \& cough were the most common symptoms. Raol \& Reddy 1991, Taneja MK 1998, Tharn bold 1958, Al Anozi et al 1998. The discharge character was mucopurulent in 31\% pt and purulent in $21 \%$ pt. the volume of discharge was copiers in 59\% and scanty in $29 \%$. Perforation was central (small \& medium) in 43\% of patients. Harendranath 1982 (73.76\%), Baruah et al 1972 (78.5\%), laxmipati \& Bhaskaran 1964 (84.1\%). Throat infection with tonsillitis of Reddy Venugopal 1998 (25\%) \& 46\% Adenoid varying grades was the major predisposing factor followed by DNS (45\%) \& URTI (44\%) Pukander Sipila \& Karma 1984, stinger up \& Tos 1986.

Streptococcus pneumonia was found in $31.8 \%$ followed by staph aureus in $27.27 \%$ E coli in $18.78 \%$ (Refr. 10, 23) \& Aspergillus (fungus) was found in $4.54 \%$ cases. In $18.18 \%$ cases the discharge was found sterile as found by Arguedas A, Loaiza C 1998, Taneza M.K. 1998.

St ph - as found by bluestone Stephenson and martin 1992 Kenna MA 1993, Black SL 1997, Robin E Huebner Auril D wasas, MT Mauria Hockman 2003, Polachek A Grunberg D 2004, Toneja M.K. 1998.

Staph aureus - Nwawolo CC Odusanya 00 200/

Antibiotic sensitivity pattern of the bacteria isolated from discharge showed cephalosporin, Amikacin, Norflox \& Ciproflox to be the most effective antimicrobial agent. Nyembu DT, Tsheswaka JM 2003 \& Alanazi et al 1998. 
Majority of pathogen showed resistant's to multidrugs including penicillin. Brook I 2004, Gok U Bulut Y 2001, Vijaya D 2000, Varshenoy et al 1989, Parveen Naheed 2000, Rqo \& Reddy 1991, Chaturve VN 1960. This is because of indiscriminate use of antibiotics even in viral infection.

\begin{tabular}{|c|c|c|c||c|c|c|}
\hline Age(year) & Male\% & Female\% & Total & \multicolumn{2}{|l|}{} \\
\hline $0-3$ & $6-10.5 \%$ & $1-2.3 \%$ & 7 & Symptoms & No. of Cases & $\mathbf{\%}$ \\
\hline $3-6$ & $7-12.3 \%$ & $8-18.6 \%$ & 15 & Discharge & 95 & 95 \\
\hline $6-9$ & $10-17.5 \%$ & $10-23.3 \%$ & 20 & Hearing loss & 56 & 56 \\
\hline $9-12$ & $26-45.6 \%$ & $16-37.2 \%$ & 42 & Cough \& Cold & 43 & 43 \\
\hline $12-14$ & $8-14.0 \%$ & $8-18.6 \%$ & 16 & Earache & 8 & 8 \\
\hline Total & 57 & 43 & 100 & Tinnitus & 8 & 8 \\
\hline Mean & $\mathbf{9 . 1 6}$ & $\mathbf{9 . 5 6}$ & $\mathbf{9 . 3 3}$ & Ear Fullness & 5 & 5 \\
$\mathbf{\pm}$ SD & $\mathbf{\pm 3 . 3 6}$ & $\mathbf{\pm 3 . 2 4}$ & $\mathbf{\pm 3 . 3 0}$ & & Table II: Study of presenting symptoms of OM \\
\hline
\end{tabular}

$\mathrm{Z}=0.60 ; \mathrm{P}>0.05$

Table I: Age \& Sex distribution of the studied cores

\begin{tabular}{|c|c|c|c|c|c|c|c|c|c|c|}
\hline $\begin{array}{c}\text { Drugs - } \\
\text { Bacteria } \\
\mid\end{array}$ & $\overline{\underline{z}}$ & 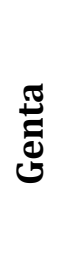 & ت & $\underset{Z}{\mathbb{Z}}$ & $\frac{\pi}{5}$ & $\frac{\grave{a}}{\frac{a}{2}}$ & 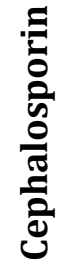 & 总 & 葛 & 希 \\
\hline Strepto & 11 & 13 & 10 & 14 & 12 & 12 & 12 & 16 & 8 & 13 \\
\hline Staph A & 14 & 25 & 28 & 29 & 26 & 28 & 34 & 32 & 15 & 9 \\
\hline Pseudo & 4 & 10 & 8 & 11 & 5 & 14 & 18 & 17 & 8 & 11 \\
\hline Klebsiella & 0 & 1 & 1 & 1 & 1 & 1 & 1 & 1 & 1 & 1 \\
\hline Proteus & 3 & 2 & 1 & 1 & 2 & 3 & 3 & 3 & 2 & 1 \\
\hline E Coli & 11 & 7 & 8 & 8 & 9 & 11 & 15 & 15 & 11 & 10 \\
\hline Total & 43 & 58 & 56 & 64 & 55 & 69 & 83 & 84 & 45 & 45 \\
\hline
\end{tabular}

Table III: Bacteriology study of Aural swab \& Antibiotic sensitivity pattern

\section{Abbreviation:-}

AOM - Acute otitis media, EAC - External Auditory canal, OM c effusion - Otitis media with effusion, ASOM - Acute Suppurative otitis media, CSOM - Chronic Suppurative otitis media, et al - and associate.

\section{BIBLIOGRAPHY:}

1. Polachek A, Greenberg D. : Etiologic agents and clinical manifestation in acute otitis media. Pediatric infectious disease journal 2004 may; 23 (5): 406.

2. Graces- Sanchez M, Diez- Domingo J.: Epidemiology and burden of acute O.M. in Valencia's (Spain). An paediatic (Bare) 2004 Feb; 600 (2): 125-32. 


\section{ORIGINAL ARTICLE}

3. Marchisio P, Claut L. Differences in nasopharyngeal bacterial flora in children with nonsevere recurrent acute otitis media and chronic otitis media. Paediatic infect Dis. J 2003 March; 22 (3): 262-8.

4. Diagnosis and management of acute otitis media. Am. Academy of Paediatrics. J. Vol. 113 no. 5: May 2004.

5. Perwin Naheed, Khan Zulfia: Bacteriological study of OM- A rural study. Indian J. of Otology Vol. 9. Dec. 2002. P. 29-32.

6. Bluestone CD, Gates GA, Klin JO et al: Panel Reports definition, terminology and classification of otitis media. Ann atol Rhinol laryngeal 2002, III suppl. 188:8-18.

7. Nwawolo CC, Odeusanya 00: Clinical profile of acute otitis media among Nigerian children. West African Journal of Medicine. 20(3)"187-90, 2001 July - Sept.

8. Vijaya D, Aerobes: Anaerobes and Fungi in CSOM. Indian Jr. of Otology Vol. 6 No. 3 (Sept. 2000): 55-58.

9. Contributing factors in otitis media. India Jr. of Otology Vol. 5 No. 3 (Sept 98), 111-114.

10. Vijaya D. Nagarathnamma T. Microbiological study of CSOM. Indian Jr. of Otology. Vol. 4 No. 4(Dec. 98), 172-174.

11. Alanazy Fatma, Saad Assiry: Microbiology evaluation and aspects on management of CSOM in Riyadh. Indian Jr. of Otology Vol 4, No. 3 (Sept. 98), 115-120.

12. Arguedas A, Loaiza C. Microbiology of acute of otitis media in costa Rican children. Pediatric infections disease Journal 1998 Aug; 17(8) 680-9.

13. Reddy, Venu Gopal: Secretory otitis media. Indian Jr. of otology Vol. 4 (4) (Dec. 98) 157-160.

14. Taneja MK: Acute otitis media. Indian Jr. of Otology Vol. 4 (4) (Dec. 1998): 161-164.

15. Gupta Vineeta, Gupta Abhay: CSOM microbiological study. Indian Jr. of Otology. Vol. 4, No. 2 (June 1998); 79-82.

16. Gulate, Sudesh Kumar: Investigative profile in patients of CSOM. Indian Jr. of Otology Vol. 3, No. 2; 1997, 59-62.

17. Rao BN, Reddy MS: CSOM A prospective study. Indian Jr. of Otology Vol 3 (2); 72-77:1994.

18. Black et al: A randomized controlled trial of surgery for glue ear. British Medical Journal. 300, 1551-1556:1990.

19. Kero P \& Piek Kakla P: Factors affecting the occurrence of acute otitis media during the first year of life. Acute Padiatrica Scandinavica. 76; 618-623:1987.

20. Brook I: Prevalence of beta-lactamase producing bacteria in CSOM. American Jr. of Diseases of children. 139; 280-83: 1985.

21. Karma et al: Middle ear fluid bacteriology of acute otitis media in neonates and very young adults. International Journal of Paediatric otorhino laryngology. 14; 141-1150:1987.

22. Ammann AZ, Shannon K: Recognition of AIDS in children. Pediatr. Rev. 7; 101-7:1985.

23. Sade J: The infant's Eustachian tube lumen pharyngeal part. Jr. of laryngology and otology. $100 ; 129-134: 1985$.

24. Tos M: Upon the relationship between secretary otitis in childhood and chronic otitis and its sequelae in adults. Jr. of Laryngology and Otology: 9; 456-464:1981.

25. Karma et al: Bacteriology of the chronically discharging middle ear. Acta otolaryngologica. 86; 110-114:1978. 


\section{ORIGINAL ARTICLE}

AUTHORS:

1. Rakesh Kumar

\section{PARTICULARS OF CONTRIBUTORS:}

1. Assistant Professor, Department of ENT, Chirayu Medical College \& Hospital, Bairagarh, Bhopal (M.P.)

\section{NAME ADDRESS EMAIL ID OF THE CORRESPONDING AUTHOR:}

Dr. Rakesh Kumar,

S-556, Nehru Nagar, Bhadbhada Dam Road, Bhopal (M.P.) - 462003.

Email-drrakes_raj@yahoo.co.in

drrakes.raj@gmail.com

Date of Submission: 31/07/2013.

Date of Peer Review: 13/08/2013.

Date of Acceptance: 17/09/2013.

Date of Publishing: 20/09/2013 